\title{
Studies on planktonic diversity in fresh water reservoirs around Amravati district, Maharashtra
}

Sangve K. B. 四

Received: 13.10.2020

Revised: 19.11.2020

Accepted: 26.11.2020

\begin{abstract}
The present study was carried out to assess the planktonic diversity and seasonal variations in the physic-chemical characteristics of Pohra, Wadali and Chhatri surface water reservoirs around Amravati during June 2014 to May 2015. During the course of study the zooplankton in the reservoir under investigation is represented by five major groups i.e. Ostracoda, Rotifera, Cladocera, Protozoa and Copepoda. Among phytoplankton a total of 28 algal species were recorded from all the reservoirs under study with 14 taxa from Chlorophyceae, 9 taxa from Bacillariophyceae and 8 from Cyanophyceae. The Chhatri reservoir was found to contain most of the pollution indicator species. Wadali reservoir also exhibited few pollution tolerant species. The water in all the reservoirs was found to be eutrophic in the order of Pohra $>$ Wadali $>$ Chhatri.
\end{abstract}

Key Words: Amravati, Phytoplankton, Planktonic diversity, Water pollution, Zooplankton

\section{Introduction}

The most diverse ecosystem in the world is the aquatic ecosystem. The first life was originated and sustained in the water and by the water (Kabra et al., 2016) where water was the principal external as well as internal medium for organism and also an essential component for survival of life on earth (Bhutiani and Ahamad, 2018; Khanna et al., 2014; Ruhela et al., 2017). India has a rich reservoir resource of more than $3.51 \mathrm{~m}$ ha (CWC 2016; Sarkar et al., 2017; Sarkar and Mishal 2017; Kumar et al., 2020). Amravati is surrounded by a large number of lakes like Wadali, Chhatri, Pohra, Basalapur, Malkhed, Sawangee, Kekatpur, Kondeshwar and many more small and large lakes and reservoirs in the aerials radius of 25 kilometers. The water of these reservoirs is also used for drinking purposes, agriculture and fishery activities. But recently, due to increasing human and grazing animal activities in it, the water is becoming polluted. The plankton community is comprised of the primary producers or phytoplankton and the secondary producers or zooplankton (Battish, 1992). Phytoplankton is the major primary producers in many aquatic systems and is important food source for other organisms (Gupta and Dey, 2012). Phytoplankton not only serves as food for

\section{Author's Address}

Department of Zoology, Brijlal Biyani Science College, Amravati. (M.S.) 444606

E-mail.: kiran.sangve@gmail.com aquatic animal, but also plays an important role in maintaining the biological balance and quality of water. Zooplankton constitutes important food item of many fishes. Plankton are the important biotic components of aquatic habitat. They do determine the trophic status and the quality of water of lakes and reservoirs. Limnology becomes a science of inland waters concerned with all the factors that influence living population within the lakes, ponds and reservoirs (Bhutiani and Khanna, 2014). In India, the lakes, dams and reservoirs are under great stress due to human activities like deforestation, grazing and removal of vegetal cover in the watershed areas. This results in accelerated silting of the reservoir. Plankton is the most sensitive floating community which is being the first target of water pollution, thus any undesirable change in aquatic ecosystem affects diversity as well as biomass of this community. Pollution status of freshwater bodies was due to the presence of some macrophytes such as Eichhornia and Lemna and rotifers as Brachionus and Keratella (Sarkar et al., 2020).

\section{Material and Methods}

\section{Study area}

The three reservoirs selected for the present study were "Pohra", "Wadali" and "Chhatri". They all are 
situated towards the East of Amravati city, India on Pohra ranges of hills. During rainy season, they get filled to their maximum capacity. Reservoir Wadali is situated at $77048^{\prime} \mathrm{E}$ longitudes and $20055^{\prime} \mathrm{N}$ latitude, reservoir Chhatri is situated at $77046^{\prime} \mathrm{E}$ longitude and 200 54' $\mathrm{N}$ latitude and reservoir Pohra is situated at 770 54' E longitudes and 200 54' N latitude.

\section{Sampling and analysis}

Water samples for analysis of various physicochemical and biological parameters were collected at monthly intervals during June 2014 through May 2015 in between 8 to 10 A.M. Parameters like water temperature $\left({ }^{0} \mathrm{C}\right), \mathrm{pH}$, turbidity (NTU), dissolved Oxygen $(\mathrm{mg} / \mathrm{l})$ and free $\mathrm{CO}_{2} \quad(\mathrm{mg} / \mathrm{l})$ were measured immediately after collection of samples at the sites by using portable battery operated water analysis kit. Estimation of total alkalinity $(\mathrm{mg} / \mathrm{l})$, total hardness $(\mathrm{mg} / \mathrm{l})$; chlorides $9 \mathrm{mg} / \mathrm{l})$; nitrates $(\mathrm{mg} / \mathrm{l})$; phosphates $(\mathrm{mg} / \mathrm{l}) ;$ sulphates $(\mathrm{mg} / \mathrm{l}) ;$ silicates $(\mathrm{mg} / \mathrm{l})$ in collected water samples were carried out in the laboratory within six hours following the standard methods as recommended by APHA (1998).

\section{Plankton analysis}

Fifty liter of water sample was filtered through the plankton net of number 25 bottling silk with mesh size $64 \mu \mathrm{m}$ and divided into two parts; one part was fixed with $4 \%$ formalin while other part with Lugol's solution. The identification of phytoplankton was done with the help of keys given by Adoni (1985) and APHA (1985). Similarly identification of zooplankton was carried out by using key and monographs of Adoni (1985) and APHA (1998).

\section{Results and Discussion}

The present investigation was carried out to know the physico-chemical status and preliminary knowledge about the flora and fauna of the reservoirs around Amravati. The Pohra reservoir was found quite cool $\left(12.6\right.$ to $\left.20.4{ }^{\circ} \mathrm{C}\right)$ in winter season while Chhatri reservoir water was found warm (26.5 to $39.4{ }^{\circ} \mathrm{C}$ ) in summer season in comparison with Wadali reservoir. The Pohra reservoir water was more transparent (510.6 to $620.2 \mathrm{~cm}$ ) during winter season and Wadali reservoir water was highly turbid $(.56-90$ NTU) during winter season. The increasing order of turbidity was observed to be Pohra reservoir < Chhatri reservoir $<$ Wadali reservoir. The $\mathrm{pH}$ was found to be in the order of Chhatri $>$ Wadali $>$ Pohra. In the Chhatri reservoir the $\mathrm{pH}$ was found to be more alkaline (8.4 to 8.9) during summer season. It is favorable for the growth of plankton, aquatic plants and fishes. Alkalinity $(\mathrm{mg} / \mathrm{l})$ of Wadali reservoir water was observed as $137.30-230.50$ $\mathrm{mg} / \mathrm{l}$, Chhatri $110.72 \quad-193.50 \mathrm{mg} / \mathrm{l}$. Sulphate contents in the Wadali reservoir exhibited 34.46 $3.42 \mathrm{mg} / \mathrm{l}$, Pohra $14.27 \quad-2.36 \mathrm{mg} / \mathrm{l}$. Chhatri reservoir exhibited high values of phosphates 42.52 $-9.39 \mathrm{mg} / \mathrm{l}$. Phosphate content $(5.6 \mathrm{mg} / \mathrm{l})$ was found in Chhatri while in Pohra it was observed as 0.002 to $0.027,0.004$ to 0.015 and 0.009 to $0.018 \mathrm{mg} / \mathrm{l}$ (Table 1). During the present investigation the zooplankton in the reservoir were represented by five major groups i.e. Ostracoda, Rotifera, Cladocera, Protozoa and Copepoda. Ostracods are represented by 2 genera, Rotifers by 13 genera, Cladocera by 5 genera, Copepods by 3 genera and protozoa by 6 genera (Table 2) in the Pohra reservoir. However, Chhatri reservoir exhibited 4 species of ostracods, 18 species of rotifers, 3 species of cladocera, 5 species of copepods and 4 species of protozoans. The Chhatri reservoir exhibited the pollution tolerant rotifers like Cephalodella, Lepadella, Monostyla and Rotarria, pollution tolerant cladocerans like Ceratodaphnia and Moinodaphnia, pollution tolerant copepods like Cyclops, Diaptomus and Ectocyclops. Our results are well in agreement with that of Kapoor (2015); Sharma et al. (2010), Kulkarni and Surwase (2013) who observed these zooplankton in various polluted water bodies. This observation indicates the presence of pollutants in Chhatri reservoir. Chhatri reservoir is situated very near to the MIDC area of the Amravati City; from which the toxic gases might be settling down in the reservoir water, polluting it. Similarly few pollution indicator species are also recorded from Wadali reservoir (Tables 2). This could be because of the human activities and entry of domestic sewage in Wadali lake.

The phytoplankton in the reservoir under investigation was represented by three major algal taxa. The Wadali reservoir water was found to contain 9 species of chlorophyceae, 7 species of bacillariophyceae and 5 species of cyanophyceae. However, Pohra reservoir was rich in algal flora. Its water showed 10 species from Chlorophyceae, 5 species from Bacillariophyceae and 6 species from 
Studies on plankton diversity in fresh water reservoirs

Table 1. Physico-chemical characteristics of reservoir around Amravati

\begin{tabular}{|l|l|l|l|l|}
\hline SN & Parameters & Pohra & Wadali & Chhatri \\
\hline 1 & Water Temperature $\left({ }^{0} \mathrm{C}\right)$ & $24.2-36.2$ & $25.2-37.6$ & $26.5-39.4$ \\
\hline 2 & Transparency $(\mathrm{cm})$ & $288.5-390.0$ & $13.6-18.9$ & $48.6-56.9$ \\
\hline 3 & Turbidity $(\mathrm{NTU})$ & $60-76$ & $62-80$ & $60-78$ \\
\hline 4 & $\mathrm{pH}$ & $8.2-8.5$ & $8.5-8.78$ & $8.4-8.9$ \\
\hline 5 & D. O. $(\mathrm{mg} / \mathrm{l})$ & $4.6-8.4$ & $4.3-7.8$ & $4.2-7.6$ \\
\hline 6 & Free $\mathrm{CO}_{2}(\mathrm{mg} / \mathrm{l})$ & Nil -28.18 & Nil-21.6 & Nil-6.3 \\
\hline 7 & Total Alkalinity $(\mathrm{mg} / \mathrm{l})$ & $139.12-189.35$ & $188.4-218.6$ & $110.72-140.25$ \\
\hline 8 & Total Hardness $(\mathrm{mg} / \mathrm{l})$ & $168.3-205.4$ & $206.6-295.3$ & $208.95-248.50$ \\
\hline 9 & Chlorides $(\mathrm{mg} / \mathrm{l})$ & $46.2-67.5$ & $108.36-145.32$ & $128.65-262.81$ \\
\hline 10 & Sulphates $(\mathrm{mg} / \mathrm{l})$ & $6.84-8.52$ & $24.62-34.46$ & $24.51-30.12$ \\
\hline 11 & Phosphates $(\mathrm{mg} / \mathrm{l})$ & $0.009-0.018$ & $0.98-1.80$ & $2.5-5.6$ \\
\hline 12 & Silicates $(\mathrm{mg} / \mathrm{l})$ & $0.065-0.186$ & $17.82-19.15$ & $22.25-26.52$ \\
\hline
\end{tabular}

Table 2. Diversity of Zooplankton in reservoirs around Amravati

\begin{tabular}{|c|c|c|c|c|}
\hline Class & Species & Pohra & Wadali & Chhatri \\
\hline \multirow{4}{*}{ Ostracods } & Cyprinotus & + & + & + \\
\hline & Cypris & + & + & + \\
\hline & Stenocypris & -- & + & + \\
\hline & Strandesia & -- & + & + \\
\hline \multirow{25}{*}{ Rotifers } & Asplanchna & + & + & + \\
\hline & Brachionus angularis & + & + & + \\
\hline & B. Calyciflorus & -- & + & + \\
\hline & B. Candatus & + & + & + \\
\hline & B. Rubens & -- & + & + \\
\hline & B. Forficula & -- & + & + \\
\hline & B. falcatus & -- & + & + \\
\hline & B. quandridentalus & + & + & + \\
\hline & B. bidentatus & -- & + & + \\
\hline & Cephalodella & -- & -- & + \\
\hline & Filinia longiseta & + & + & - \\
\hline & F. opeliensis & + & - & - \\
\hline & F. ovalis & + & - & - \\
\hline & Keratella cochlearis & & - & - \\
\hline & K. tropica & + & + & + \\
\hline & K. quadratus & + & + & + \\
\hline & Lecane luna & + & - & + \\
\hline & L. bulla* & - & + & + \\
\hline & Lepadella & - & + & + \\
\hline & Monostyla* & - & + & + \\
\hline & Mytilina & + & + & - \\
\hline & Notcholca & + & + & + \\
\hline & Rotarria* & - & + & + \\
\hline & Testudinella & - & + & - \\
\hline & Trichotria & + & + & - \\
\hline \multirow{3}{*}{ Cladocerans } & Alonella & + & + & -- \\
\hline & Ceratodaphnia* & -- & + & + \\
\hline & Daphnia & + & + & -- \\
\hline
\end{tabular}




\section{Sangve}

\begin{tabular}{|c|c|c|c|c|}
\hline & Diaphanosoma & + & + & -- \\
\hline & Leydigia & -- & -- & + \\
\hline & Macrothrix & + & + & -- \\
\hline & Moinodaphnia* & -- & + & + \\
\hline & Simocephalus & + & + & -- \\
\hline \multirow{8}{*}{ Copepods } & Cyclops* & -- & + & + \\
\hline & Diaptomus* & -- & + & + \\
\hline & Ectocyclops* & -- & + & + \\
\hline & Mesocyclops & -- & + & + \\
\hline & Nauplius & + & + & + \\
\hline & Neodiaptomus & + & + & -- \\
\hline & Phyllodiaptomus & + & + & -- \\
\hline & Thermocyclop & -- & + & -- \\
\hline \multirow{7}{*}{ Protozoons } & Arcella & + & + & + \\
\hline & Centropyxis & + & + & -- \\
\hline & Difflugia & + & + & + \\
\hline & Euglena & + & + & -- \\
\hline & Euglypha & + & -- & -- \\
\hline & Paramoecium & -- & -- & + \\
\hline & Vorticella & + & + & + \\
\hline
\end{tabular}

Table 3. Diversity of Phytoplankton (Algal taxa) in reservoirs around Amravati

\begin{tabular}{|c|c|c|c|c|}
\hline Class & Species & Pohra & Wadali & Chhatri \\
\hline \multirow{14}{*}{ Chlorophyceae } & Ankistrodesmus & + & + & + \\
\hline & Chara & + & + & + \\
\hline & $\underline{\text { Chlorella }}$ & -- & + & + \\
\hline & Clostridium & -- & + & + \\
\hline & Cosmarium & + & + & -- \\
\hline & Merismopodia & + & -- & -- \\
\hline & Mesotaenium ${ }^{*}$ & -- & + & + \\
\hline & Oedogonium & + & + & -- \\
\hline & Pediastrum & + & -- & -- \\
\hline & Phacus & + & -- & -- \\
\hline & Scenedesums & -- & -- & + \\
\hline & Spirogyra & + & + & - \\
\hline & Tetradron & + & -- & -- \\
\hline & Ulothryx & + & + & -- \\
\hline \multirow{9}{*}{ Bacillariophyceae } & Amphora & + & + & + \\
\hline & Cyclotella* & + & + & -- \\
\hline & Cymbella* & -- & + & + \\
\hline & Epithemia & + & + & -- \\
\hline & Gomphonema & + & + & -- \\
\hline & Navilula* & -- & + & + \\
\hline & Nitzschia $^{*}$ & -- & -- & + \\
\hline & $\underline{\text { Rhophalodia }}$ & + & + & -- \\
\hline & Synedra* & -- & -- & + \\
\hline Cyanophyceae & Anabaena & + & + & -- \\
\hline
\end{tabular}




\begin{tabular}{|l|l|l|l|l|}
\hline \multirow{5}{*}{} & Chrocoocus & + & + & -- \\
\cline { 2 - 5 } & Lyngoya & + & + & -- \\
\cline { 2 - 5 } & Microcystis* & -- & -- & + \\
\cline { 2 - 5 } & Nostoc & + & -- & -- \\
\cline { 2 - 5 } & Oscillatoria* & -- & + & + \\
\cline { 2 - 5 } & Phormedium & + & -- & -- \\
\cline { 2 - 5 } & Syunechocystis & + & + & -- \\
\hline
\end{tabular}

*: Pollution Indicator Species. + : Present -- : Absent

Cyanophyceae. The Chhatri reservoir represented less number of algal taxa. It represented only 5 species of chlorophyceae, 5 species of bacillariophyceae and only two species from cyanophyceae. In all 28 algal species were recorded from all the reservoirs under study with 14 taxa from Chlorophyceae, 9 taxa from Bacillariophyceae and 8 from Cyanophyceae. Pohra reservoir exhibited 10 chlorophyceae members, 5 bacillariophyceae taxa out of 9 and 6 taxa out of 8 from cyanophyceae (Table 3). The Chhatri reservoir represented less number of algal taxa. It represented 9 species of chlorophyceae, particularly Ankistrodesmus, Chara, Clostridium, Mesotaenium, Scenedesmus, Chara, Clostridium, Mesotaenium and Scenedesmus. Similarly 5 species of bacillariophyceae were also found in Chhatri reservoir which includes Amphora, Cymbella, Navicula, Nitzschia and Synedra. However, Chhatri reservoir was found to contain only two species from cyanophyceae namely Microcystis and Oscillatoria. The high amount of dissolved oxygen during winter might have enhanced the growth of Anabaena, Merismooedia, Cyclotella, Cosmarium in Pohra and Wadali reservoirs. This is in agreement with Ganpati (1970). Chhatri reservoir exhibited, the pollution indicator algal species, Mesotaenium, Cyclotella, Cymbella, Nitzschia,

\section{References}

Adoni, A. D. 1985. Workbook on Limnology; Indian MAB Committee., Deptt. Of Envoronment., Govt. of India.

APHA 1998. Standard methods for examinations of water and waste water $\left(20^{\text {th }}\right.$ Ed.), American Public Health Association, Washington D.C.

Battish, S. K. 1992. Freshwater zooplankton of India. Published by oxford \& IBH publishing Co.PVT.LTD. New Delhi.
Synedra, Microcystis and Oscillatoria.

\section{Conclusion}

In the present study various physicochemical and biotic components of the Pohra, Wadali and Chhatri reservoirs were investigated. During the investigation Chhatri reservoir water showed large number of pollution indicator species of zooplankton and phytoplankton while Pohra reservoir did not show any pollution tolerant species neither from flora nor from fauna. With respect to the degree of pollution the sequence of the three reservoirs was found as Chhatri $>$ Wadali $>$ Pohra. Wadali reservoir is becoming polluted day by day as its oligotrophic nature is on the verge of becoming entrophic. From the above study it may be concluded that Chhatri reservoir was found polluted while there is an alarming situation for Wadali reservoir on the other hand Pohra lake was found safe from pollution.

\section{Acknowledgement}

I express my sincere thanks to (Late) Dr. G.N. Vankhede Professor and Head, Department of Zoology, Sant Gadge Baba Amravati University, Amravati for valuable guidance and for providing necessary laboratory facilities to carry out this work.

Bhutiani, R. and Ahamad, F. 2018. Efficiency assessment of Sand Intermittent Filtration Technology for waste water Treatment. International Journal of advance research in science and engineering (IJARSE), 7(03): 503-512.

Bhutiani, R. and Khanna, D. R. 2014. Qualitative studies on planktonic diversity of River Ganga at Haridwar. Biotechnology International, 7(4): 101-108.

CWC 2016. National register of large dams. Central water commission. http://www.cwc.nic.in/main/downl oads/new\%20nrl d.pdf. Accessed 20 Apr 2019 
Ganpati, S. V. 1970. Energy flow in natural aquatic ecosystem in India. Arch. Hydrobiology, 66: 458-498.

Gupta, T. and Dey, M. 2012. Hydro biological Characteristics of Some Semi-intensive fish culture ponds of Lumding town of Nagaon district, Assam. Current World Environment, 8: (1).

Kabra, P. D., Somatkar, J. R. and Dabhade, D. S. 2016. Quantitative Analysis of Zooplanktons of Fresh Water Ecosystem in Washim Town, Maharashatra, India. Indian Streams Research Journal, 6(5): 1-7.

Kapoor, P. A. 2015. Study on Ecology of zooplankton profusion in Bhoj wetland, India. International scholars journals, 3(6): 249-260.

Khanna, D. R., Bhutiani, R., Tyagi, V. and Ahamad, F. 2014. Impact of Sugar Mill Effluent on Physico-chemical Properties of Malin River at Najibabad, Bijnore. Indian Journal of Scientific Research (Special edition), : 5-10.

Kulkarni, D. A. and Surwase, S. S. 2013. Studies on Occurance, Richness and Composition of Zooplankton in Seena river water at, Mohal, Dist- Solapur, MS, India. International Research Journal of Biological Sciences, 2(2): $25-28$.

Kumar, J., Alam, A., Sarkar, U. K., Das, B. K., Kumar, V. and Srivastava, S. K. 2020. Assessing the phytoplankton community and diversity in relation to physico-chemical parameters in a tropical reservoir of the River Ganga basin, India. Sustainable Water Resources Management, 6:110, https://doi.org/10.1007/s40899-020-00470-z
Ruhela, M., Bhutiani, R. and Ahamad, F. 2017. Pollution Status of River Hindon from Ghaziabad to Noida with Special Reference to Heavy Metals. International Journal of Advance Engineering and Research Development, 4(8): 540-548.

Sarkar, R, Ghosh, A. R. and Mondal, N. K. 2020. Comparative study on physicochemical status and diversity of macrophytes and zooplanktons of two urban ponds of Chandannagar, WB, India. Applied Water Science, 10: 63.

Sarkar, U. K. and Mishal, P. 2017. Status, potential and prospects of reservoir and wetland fisheries in India-an overview. In: Mohanty BP et al (eds) Souvenir of national seminar on priorities in fisheries and aquaculture. ICARCentral Inland Fisheries Research Institute, Barrackpore, pp 171-185.

Sarkar, U. K., Sandhya, K. M., Mishal, P., Karnatak, G., Kumari, L., Pannikar, S., Palaniswamy, P., Karthikeyan, R., Mol, M., Paul, S. S., Ramya, T. T., Rao, V. L., Khan, D. S. K., Panda, M. F. D. and Das, B. K. 2017. Status, prospects, threats and the way forward for sustainable management and enhancement of the tropical Indian reservoir fisheries: an overview. Reviews in Fisheries Science \& Aquaculture, 26(2): 155-174.

Sharma, S. P. and Saksena, D. N. 1981. Zooplanktonic fauna of some perennial impoundments at Gwalior, India. Journal of Jiwaji University, 9(112): 73-92.

Sharma, S., Siddique, A., Singh, K., Chouhan, M., Vyas, A., Solnki, C., Sharma, D., Nair, S. and Sengupta, T. 2010. Population Dynamics and Seasonal Abundance of Zooplankton Community in Narmada River (India). 3741 researcher 0209, 2 (9): 1-9. 